\title{
The Terracotta of Kyphosis Old Man From Faiyum Preserved in Egyptian Museum in Cairo Publication and Study
}

\author{
Mustafa Muhammad Qandil Zaied* \\ Professor of History of Ancient civilization King Khalid University. Faculty of Humanities, KSA \& Professor of \\ classical Archaeology Ain Shams University, Faculty of Arts, Egypt
}

\begin{abstract}
*Corresponding Author: Mustafa Muhammad Qandil Zaied, Professor of History of Ancient civilization King Khalid University. Faculty of Humanities, KSA \& Professor of classical Archaeology Ain Shams University, Faculty of Arts, Egypt
\end{abstract}

\begin{abstract}
Terracotta figurines - as a part of minor arts - have been produced and widely used throughout the long period of Graeco Roman dominance over Egypt. They were cheaply made of fired Nile clay and display a wealth of motifs unparalleled in any other terracotta workshops from the ancient world, so this paper aims to shed the light on a rare terracotta figurine at Gallery No. 39 in the Egyptian Museum in Cairo. The artistic features of the figurine clearly suggest that it goes back to the Roman era. This terracotta figurine was never studied or published before. Furthermore, this piece was selected carefully by the author to represent kyphosis old man who porter the lantern which refers to different aspects of the daily life at that time. The author compares this figurine to other one's, all depicting men while practicing their professions or carrying tools that refer to the nature of their profession.
\end{abstract}

Key words: Terracotta - Grotesque - Kyphosis - Old Man - Lantern - Roman Era - Faiyum.

\section{INTRODUCTION}

In the terminology of archeologists specialized in Classical archeology, the terracotta art refers to figurines that were made out of raw clay specially during the Hellenistic and Roman eras. In fact, this art is rich in innovation whether in hand-made figurines or those modeled. It is also rich as far as variety of themes is concerned. However, this art represents the lowest class in society ${ }^{1}$. It goes without saying that bronze and marble sculptures represent often the higher classes of society in view of the high costs and high degree of skills required for modeling and molding compared to raw clay sculpture. Meanwhile, the terracotta art is likewise skillfully-produced and is even superior to other arts as regards the diversity of its themes.

From the fourth century B.C.E onwards, small-scale sculpture developed a rich repertoire of ridiculous and grotesque types that set a trajectory different from public and conspicuously visible $\operatorname{art}^{2}$. The so-called grotesques were an enhancement of the Hellenistic and Roman interest in the human body and its weakness and imperfections by depicting ill and deformed individuals. Their variety ranges from representations of clinically diagnosable deformities to exaggerated physical abnormalities. ${ }^{3}$

This research paper aims at spotting light on the terracotta of kyphosis oldman, Registry No. 33425, Height: $13 \mathrm{~cm}$. from Qasr Al Banat ${ }^{4}$, preserved at the Gallery No. 39 in the Egyptian Museum in Cairo.

\footnotetext{
${ }^{1}$ Barrett, C., 2015: $401-419$.

${ }^{2}$ Walters, H., 1914: XXVII.

${ }^{3}$ Voegtle, S., 2016: 6.

${ }^{4}$ Located in south-west of Al-Faiyum is Qasr Al-Banat, site of Euhemeria. It is originally built on a series of low mounds some kilometers east Quarun's Castle and southwest Lake Moeris. Excavates in the region discovered a small temple for worshipping Sobek and Osiris. The city gained a great reputation during the Ptolemaic and Roman eras. In fact, an inscription was discovered that is dated at the reign of Ptolemy XI and his wife. Moreover, a considerable number of papyri and Greek ostraca were excavated there along with some
} 
Actually, its artistic features reveal that belong to the Roman era. The most eye-catching feature of this Terracotta is that it has never been studied or published before. Furthermore, it was selected carefully by the author to represent very important issue referring to the aspects of daily life. This terracotta can be descriptively and analytically studied. Moreover, an attempt shall be made to define its dating based on their artistic features or models, through comparing it to their peers whose chronology is known or according to the place where this piecewas excavated.

\section{DISCUSSION}

The visual arts of the period - bronze and terracotta figurines in particular - reveal fascination with people exhibiting various physical deformities: images of cripples, dwarfs, and hunchbacks abound, and realism is considered a particular feature of Hellenistic and later of Roman art ${ }^{5}$. It is an admirable piece of naturalistic terracotta, and a distinctive piece of art depicting an old hunchback ${ }^{6}$, carrying a lantern $^{7}$ or "lanternarius"8. The lantern-bearer is depicted as elderly man with emaciated body, wearing a short chiton reaching to the knee and seemingly having no sleeves (fig. $1 \mathrm{~A}$ ). Above the chiton there was a himation that is wrapped around his neck and hanging on back his shoulders and on his back.

The face is depicted as oval with a short hair thinned a little backwards. The eyebrows are thick and the nose is big and straight. Eyes are skillfully shaped and the ears are relatively big. The face features express disgust obviously and this is shown in the upper lib is raised, the lower lip is slightly protruding, the nose is wrinkled, the cheeks are raised, lines show below the lower lid, and the lid is pushed up but not tense, the brow is lowered, which lowers the upper eye lid $^{9}$. Hence, this emotion of disgust corresponds completely to disability and age with the nature of work. And the lean body speaks of privation and physical misery ${ }^{10}$.

The artist successfully portrayed the natural movement of the old hunchback while carrying the lantern. He portrayed the left hand as going backwards while the right leg is advancing forward. In every detail the artist shows an unsparing realism and the most observation of an abnormal subject. It seems as if the artist captured by a camera the moment of his walking or a scene from an Egyptian street $^{11}$. In fact, the man is looking just below his feet, which is natural for an old, especially a handicapped, man walking in the street. In addition, this look also indicates a complete focus of attention on the road especially since he is carrying a heavy load that might cause him hardship while walking. Furthermore, the artist skillfully portrayed the lantern carried by the man as touching the ground, which precisely expresses how the lantern is burdensome for the man.

Portraying the old age was through the wrinkles on the forehead and the hair that is thinned backwards. Moreover, the artists skillfully depicted the handicap through portraying the upper part of the man as bending and as rushing forward while walking. This is in addition to the big protruding part at the top of the figurine's back, so this figurine show oldman suffering from illness of

statues, coins, lamps, pottery vessels, terracotta and other things. See: Grenfell, P. \&. Hunt, A., 1899: 8-15; Nur Al-Din, A., 2002: 145.

5 Pollitt, J., 1986: 127-149; Fowler, B., 1989: 44-78; Zanker, G., 2004: 124 - 143; Muratov, M., $2012: 56$. Stewart, A., 2014, $172-175$.

${ }^{6}$ Hunchback or kyphosis is the extreme curvature of the upper back also known as roundback. Spinal birth defects can result in a fixed, exaggerated curve. It can also result from degenerative diseases or be caused by several other reasons. In fact, Egyptian art often depicted the hunchback since the predynastic era till the era of late dynasties. Likewise, the Alexandrian art depicted hunchback during the Ptolemaic and Roman eras. There are some examples in the Egyptian Museum and the Museum of Berlin reflecting the status of the hunchback in the Egyptian society during the Ptolemaic and Roman eras. See:

Leca, A., 1983: 433-434; Himmelmann, N., 1983: 61-64; Kozma, Ch., 2010: 2561, fig.12.

${ }^{7}$ About Roman lanterns see, Bailey D., 1975, cat.no.Q609; Dunand F., 1976:71-85, pls.III-XVI; Smoláriková, K., 2016: 29, fig.2.

${ }^{8}$ Perdrizet, P., 1921: 18-19; Dunand, F., 1965: 71-95.

${ }^{9}$ Ekman, P. and Friesen, W., 2003, 76.

${ }^{10}$ We can compare it, whence lean body, with a terracotta from Tarsus, see Goldman, H., 1943: 24, fig.1.

${ }^{11}$ See Karoglou, K., 2016: 1 - 9. 
kyphosis ${ }^{12}$ (fig.1B). The closest parallel to this terracotta statuette is given by a small bronze statuette at Vienna ${ }^{13}$, and an ivory statuette at British Museum, it measures 4 in., and dates to Hellenistic Period and perhaps made in Alexandria, Egypt. ${ }^{14}$. We can compare it, whence the hunchback form, with marble bust of a hunchback in the Villa Albani-Torlonia in Rome, which dated by the second century $\mathrm{CE}^{15}$.

As for the color of the raw material the figurine is made of, it is dark brown, which is in line with the nature of the place where the figurine was excavated, i.e. the Faiyum region which was inundated by the annual flood ${ }^{16}$. The flood carried the Nile siltt ${ }^{17}$, which is rich in the iron element. Thus, the figurine takes the dark brown color after burning.

As for the technique employed in making this piece of art, its front part is made through modeling while the back of the figurine is left unshaped (pl. $1 \mathrm{~B}$ ). However, the haunch is protruding along with another part at the back's top to signify the handicap. ${ }^{18}$ Perhaps this is the reason why the artist abnormally placed the hole on the front near the knee hardly perceivable because of the bend (fig.1A). The head, however, is more likely shaped separately from other parts of the figurine and were later attached to it before the burning process. Although the method of modelling the terracotta figurines by hand did not disappear, they were generally produced by using two-piece moulds ${ }^{19}$. This, however, did not mean that the resulting products were perfectly identical to each other. After taking a semifinished statuette out of the mould the craftsmen could still carry out minor changes with a modelling tool before firing. In fact, by attaching separately made, hand-modelled details to the moulded figurines their entire meaning could even be altered ${ }^{20}$.

As to the theme depicted, the figurine seems to represent the profession of lighting streets, or elsewhere, by lanterns ${ }^{21}$. Curiously, among those who practiced it were old and handicapped men, which reflects the high esteem this group of people were held by the society at that time. In fact, the existence of a physical distortion or a handicap during the earlier years of age used to signify a divine bounty and to inspire respect. ${ }^{22}$ Moreover, a hunchback used to be considered a good omen bringing about good luck ${ }^{23}$, especially a hunchback figurines used as charms against the Evil Eye ${ }^{24}$. It might also happen that handicap occurs as a result of work incident or that he practiced a specific profession that required carrying heavy loads. This is why the society held them in such a high esteem.

\footnotetext{
${ }^{12}$ Laios, K., and Others, 2016: 571.

${ }^{13}$ Yeames, A., 1907: 279-282.

${ }^{14}$ British Museum. Object reg. no: GR 1814, 0704.277.; Kozma, Ch., 2010: 2561, fig. 12.

${ }^{15}$ Bol, R., 1989: 227 - 31; Trentin, L., 2010: 130.

${ }^{16}$ Since the earliest ages and up till now, Faiyum is an oasis or a depression in the desert immediately to the west of the Nile. The basin floor comprises fields watered by a channel of the Nile, the Bahr Yussef, as it drains into a desert depression to the west of the Nile Valley. It branches out of the Nile, draining into the large saltwater Lake Moeris - "Moeris" is a Greek adaptation of ancient Egyptian Mer-Wer (= "The Great Canal"). It persists in modern times as a smaller lake called Birket Qarun. In fact, this oasis gained a great reputation during the Ptolemaic and Roman eras and was mentioned in the records of Greek and Roman travellers such as Herodotus, Strabo and Diodorus Siculus. They stated that the lake was used as a reservoir to store surpluses of water for use during the dry periods. See: Nur Al-Din, A., 2001: 150-151.

${ }^{17}$ Prinz, H., 1908: 84-86.

${ }^{18}$ The case of this man is diagnosed as kyphosis, which is the extreme curvature of the upper back also known as roundback that can be the result of birth defects. See: Dawson, R., 1927: 325; Rifaat, A., 1958: 551-554; Goldman, H., 1934: 22-34, fig. 10.

${ }^{19}$ De Rosa, K., 2014: 2.

${ }^{20}$ Higgins, R., 1969: 98-99; Muller, A., 1997: Westenholz, J., 2005:11 - 12; 447-448; Süvegh, E., 2014: 144; Ferruza, M., 2017: 3 - 4.

${ }^{21}$ Breccia, E. 1926: 72-77; Dunand, F., 1965: 71-95; Bailey, D. M. 1971-72: 101-2, pl. 32a; Bagatti, B. 1972:39-41, fig.5; Bussière, J., \& Wohl, B., 2018,: 445. Figs.610, 611.

${ }^{22}$ Wace, A., 1904: 109 - 11; Halioua, B., 2004: 123.

${ }^{23}$ Certain grotesque figures like the Egyptian god Bes (and its Greek adaptions) had special functions. Worn as an amulet it protected pregnant women and newborn children see. Plut., Quaest. conv. 5.7 (681-682); Varro, Ling.7.97; Giuliani, L. 1987:701-721; Torok, L., 1995: 159; Dasen, V., 2015: 46-47; Voegtle, S., 2016: 6; and grote

${ }^{24}$ Wace, A., 1904: 109.
} 
Actually, medical studies ${ }^{25}$ revealed that, in addition to the hereditary factor, round back can be the result of the nature of the profession practiced by the hunchback. In fact, the way one sits affects the longissimus. Examples of profession that can cause this are scribes and jewelry makers. Moreover, carrying heavy loads in an improper manner can have a negative effect on shoulders and the back and thus cause round back. Furthermore, round back can be the result of osteoporosis or self-limiting skeletal disorder. Moreover, there is a type of kyphosis commonly attached to old age.

It is also noteworthy that the Egyptian Museum contains another collection of terracotta pieces including one that is not included here. ${ }^{26}$ It depicts an old hunchback wearing a turban on his head and very hardly trying to walk. The broad forehead, the way the eyes are carved and the way the folds of clothes are shaped indicate that this piece is dated at the end of the second century AD or, more specifically, are in line with the artistic features of the Severan era $^{27}$. In this regard, the importance of this piece is its signifying that handicapped persons used to take part in public life during the Roman era. To this effect, it is important to note that the source of this piece is probably the Faiyum region since its color resembles that of the man carrying the lantern (figs.1 A, B). This suggestion is also supported by another piece whose source is Faiyum and that is preserved in the Egyptian Museum too. ${ }^{28}$ This latter piece can be compared to the two former pieces as far as shape, color and theme are concerned. Besides, the Roman Museum is also full of a good number of terracotta figurines that depict similar themes including a headless figurine of a hunchback. ${ }^{29}$

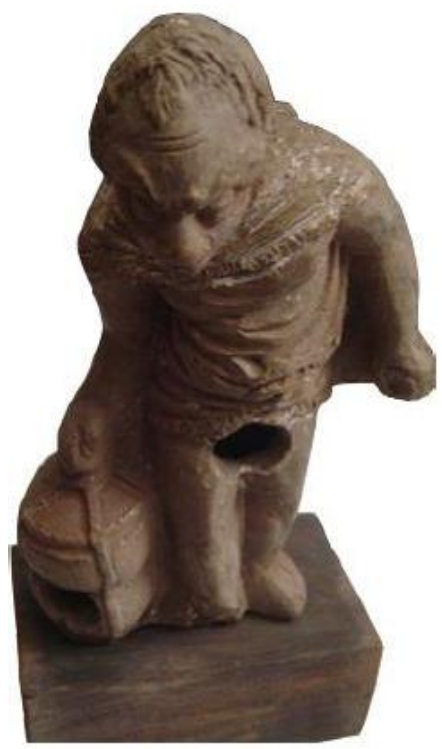

fig.1A

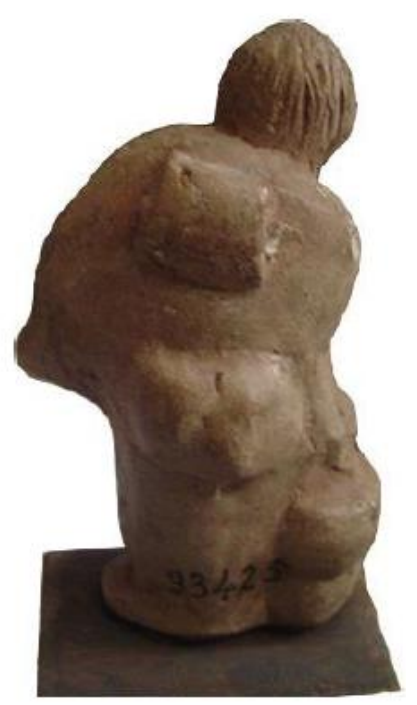

fig.1B

In fact, lanterns and lamps were not used in lighting streets only but also in domestic, public, commercial and religious contexts. Within the home the desire for artificial light, other than the light produced from hearths, fireplace or torches, may well relate to activities such as reading, writing and dining. The use of lamps by any individual would have transformed their perception of any area of their abode, influencing the way in which they dictated their activities and movements within the space. Public buildings and commercial spaces from theatres to shops would have also required lamps for illumination, along with torches or fire-baskets, when a larger light source was needed ${ }^{30}$.

We can compare this terracotta figurine, as sample of profession lighting streets or elsewhere, by marble statuettes of a drowsy child ${ }^{31}$, sitting on a stone and wearing a short cloak, with a hood

${ }^{25}$ Haeger, K., 1988: 150; Rifaat, A., 1958: 553.

${ }^{26}$ The Egyptian Museum, registry No.: 27330, height $7.5 \mathrm{~cm}$, unknown source.

${ }^{27}$ Vermeule, C., 1968: 552.

${ }^{28}$ The terracotta is unpublished and preserved in the Egyptian Museum, registry No.: 43546, height $8.5 \mathrm{~cm}$, source: Faiyum.

${ }^{29}$ The Greek Roman Museum, registry No.: 6538, height $8 \mathrm{~cm}$, source: The Black Head.

${ }^{30}$ Eckardt , H., 2002: 16; De Rosa, K., 2014: 2.

${ }^{31}$ About a sleeping child, Eros see, Hemingway, S., Stone, R., 2019: 47 - 63. 

and Study

covering the top of his head ${ }^{32}$, which is supported by his left hand and arm, there is three copies of these marble statuettes, in the National Museum of Rome(fig.2) ${ }^{33}$, in the Altes Museum at Berlin (fig. 3$)^{34}$, and in the Antiquities Museum of the Library of Alexandria, Egypt (fig.4) . $^{35}$. Another bronze figurine, of an African adult servus lanternarius ${ }^{36}$, is in the National Archaeological Museum of Cagliari, Sardinia, dated by second half of the 3rd cent. C. E. Many samples of terracotta depicted a boy with negroid features, wearing cucullus, beside himlantern, set on base with moulding, dated by first half of 3rd cent. C.E ${ }^{37}$.We can compare it too witha hanging ceramic lamp of British Museum ${ }^{38}$, as terracotta group of ayoung man and his slave boy, who carries a lantern to light the way home.

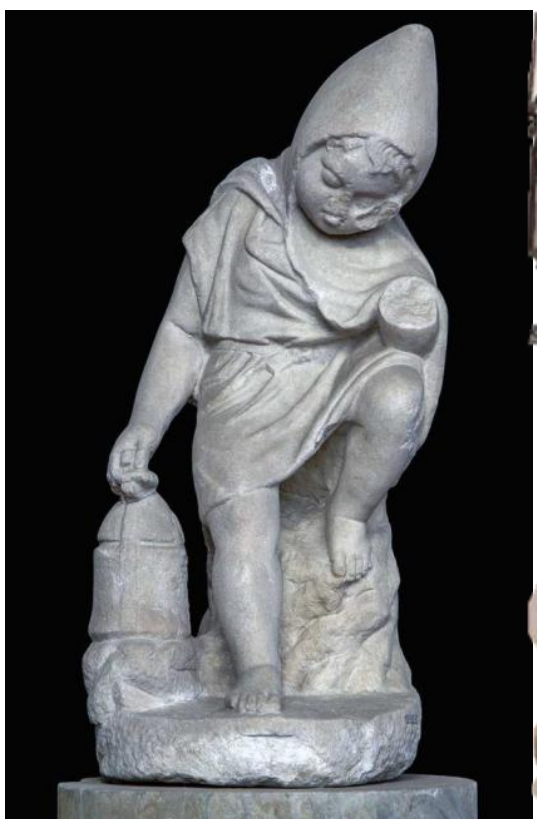

Fig.2

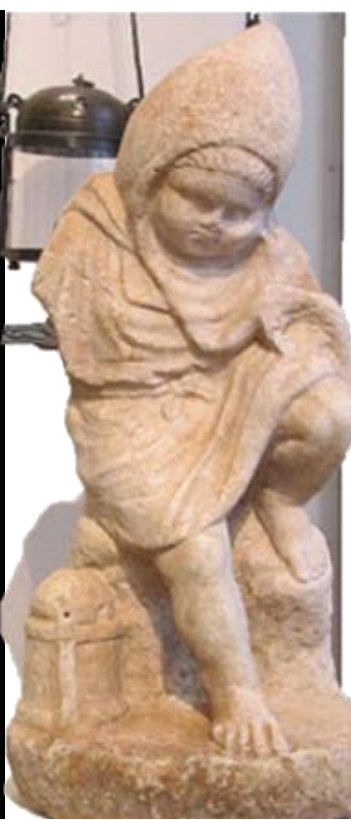

fig. 3

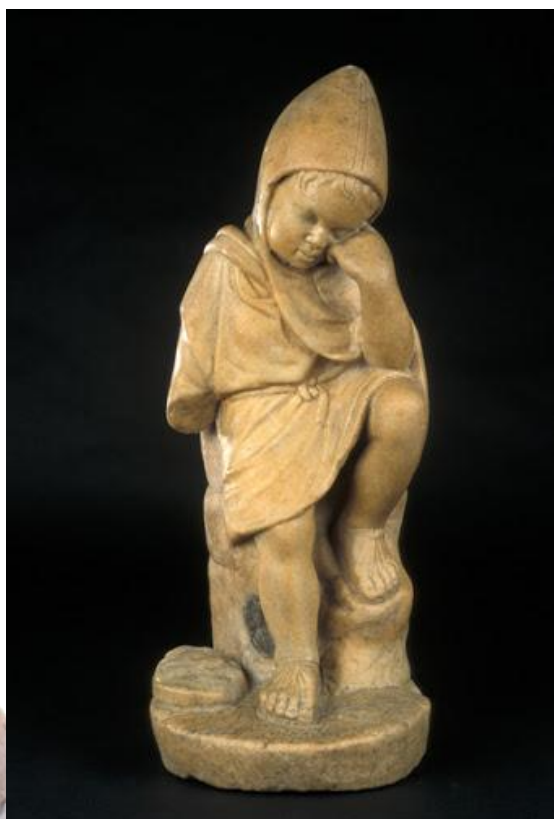

fig.4

It is noted that the lantern style of the Egyptian Museum model (fig.1A, B) is a cylindrical body crowned from the top in a conical shape above the circular opening used for hanging, it includes a square hole in the body that was mostly used in the lighting process ${ }^{39}$, the same lanterns style of National Museum of Rome (fig.2), Altes Museum at Berlin (fig.3), and the Antiquities Museum of the Library of Alexandria, Egypt (fig.4). There is the same style of four lanterns discovered in Faiyum, preserved in Greco - Roman Museum at Alexandria ${ }^{40}$.It's indicates the spread of this style in Egypt,

\footnotetext{
${ }^{32}$ Jung noticed how much the figure of the hooded lanternarius was akin to some representations of a "minor" Hellenic deity: Telesphorus ("the accomplisher"), mythical son and assistant of Asclepius, god of medicine. In the so named "Stone of Bollingen", who roams through the dark regions of this cosmos and glows like a star out of the depths He points the way to the gates of the sun and to the land of dreams, Jung, C., 1963: 215. Or It is the shape of an individual entirely wrapped in a funerary bandage, which leaves only the face uncovered as Osiriform like terracotta lamp found in House C11 at Karanis "Fayium" preserved in Kelsey Museum 6478, and a bronze lamp, preserved in the Museum of Hatay (Antakya, Turkey ((inv. no. 7587), dated of the endof third centuries CE,see, Gazda, E., 1924-1935: 40, fig. 70; Lafl1, E., Buora,M., Mastrocinque, A., 2012: 422, fig. 1; Abdelwahed,Y., 2015:34 -35,figs.1-2.

${ }^{33}$ From Baths of Diocletian; unfortunately, today the left arm of the sleepy child is missing, Museo Nazionale Romano, inv. 125587.

${ }^{34}$ From Acquired in Rome 1909. Altes Museum, Garden, Berlin, as part of a lot of 80 artefacts from rural villas in the modern municipalities of Boscoreale, Boscotrecae and Scafari, near Pompeii, which were destroyed by the eruption of Vesuvius in $79 \mathrm{AD}$.

${ }^{35}$ Provenance from Lower Egypt, Kafr El-Shiekh (Borollos lake), Height:

$62 \mathrm{~cm}$, Registration Number(s) BAAM Serial 0860.

${ }^{36}$ Thiessen, K., 2016: 2- 8.

${ }^{37}$ Grandjouan, C., 1961: 80. Pl.30, figs.1062, 1063, 1064.

${ }^{38}$ From Thebes, Egypt British Museum, EA37561;Walker, S., Higgs, P., 2000: 35 ; Walker, S., Higgs, P., 2001: 90.

${ }^{39}$ Perdrizet, P., 1921: 19, pl.LXXX, 47; Breccia, E., 1943: 47, pl.LXXIV, 378- 79; Dunand, F., 1965: 79.

${ }^{40}$ Graeco-Roman Museum, Inv.8420, 8421, 8424, 8426.
} 
especially Faiyum, because the Egyptian Museum Terracotta (fig.1A, B) was discovered in Faiyum, and then it became popular in the entire Roman world.

Actually, it is worth mentioning that Faiyum was the center of most of the burnt clay industry during the Roman era. To this effect, this region witnessed a great boom in all fields, especially the terracotta art, during this era. Moreover, Alexandria's role relatively faded out in this field. Furthermore, clay figurines that were excavated in Faiyum are dated at the second century AD because they were excavated along with some coins that are proven to be dated at the second century AD. ${ }^{41}$ Thus, this piece is more likely dated at the end of second century AD.

\section{CONCLUSION}

Through the above presentation of this rare terracotta, we can deduce a number of conclusions:-

In this study we offer a rare terracotta figurine used in the mixed society of Roman Egypt, which elucidated the elderly are not an isolated or isolable segment of society; they are integral to it, their situation and their needs are indissolubly meshed into the basic structure of society.

It became clear that a terracotta, and marble statuettes too, represents profession of lighting in the Egyptian society during the Roman era. This profession reflected the activities in the Egyptian street at that time. Specifically, the male only practiced it, as may suit the physical ability and bodily structure of men. In fact, we came across no evidence proving that females practiced this profession in society. Rather, the terracotta art depicts them as performing such ordinary housework activities as cooking, weaving and spinning or playing games for amusement. In addition, terracotta art is rich in a wide-range variety of female clothes, haircuts and the like. The clearest evidence for a skillful depiction of the world of females is Tanagra figurines.

The study also revealed that this terracotta figurine was shaped through modeling, marked by the existence of one hole in insignificant or unshaped area of the piece of art, and the lantern style of it( fig. 1A,B) became famous and probably its origin Fayoum region and then spread to Egypt and the Roman world. The end of second century dating of this piece of art based on the artistic features characterizing a given that era and through comparing the pieces at hand to other examples whose date is known and that have the same artistic features.

Moreover, the study reached the indisputable conclusion that the Roman society used to hold elderly and handicapped people in a high esteem and would assign to them such occupations suitable for their health conditions as lighting the streets or public edifices.

Furthermore, the study spots light on the different stages of ages of the males who practice that profession ranging from young boys at an early age (figures 2 - 4), youth, manhood, and old age (figure 1). No doubt, this indicates that the society made use of all human energies and powers and was keen to make the utmost benefit out of leisure time.

\section{BIBLIOGRAPHY}

[1] Abdelwahed,Y., 2015,"The Illumination of Lamps (Lychnokaia) for Neith in Sais/Esna in Greco-Roman Egypt", Abgadiyat, Issue No. 10.

[2] Adriani, A., 1948. Alessandrina documenti recerche d'arte alessandrina II, Rome.

[3] Aelian. Historical Miscellany. Translated by N.G. Wilson. Loeb Classical Library No. 486. Cambridge, MA: Harvard University Press, 1997.

[4] Allen, M.L., 1985. The Terracotta Figurines from Karanis: A Study of Technique, Style and Chronology in Fayoumic Coroplastics, 2 vol., UMI, Ann Arbor.

[5] Bagatti, B. 1972. "Incensieri e portalucerne fittili in Palestina nei secoli II-VII." Rivista di Archeologia Cristiana 48.

[6] Bailey, D. M. 1971-72. "Some Recent Lamp Acquisitions in the Department of Greek and Roman Antiquities." The British Museum Quarterly 36.1-2.

[7] Bailey D.M., 1975, A catalogue of the lamps in the British Museum I,Greek,Hellenistic and early Roman Pottery Lamps ,London.

${ }^{41}$ Dunand, F., 1990: 10. 
[8] Bailey, D. M. 2006. Terracotta and plaster figurines, sealings and a stone group. In Mons Claudianus 3, Ceramic vessels and related objects, 261-88, V. Maxfield and D. P. S. Peacock (eds). Cairo.

[9] Bailey, D.M. 2008. Catalogue of terracottas in the British Museum. Vol. IV: Ptolemaic and Roman terracottas from Egypt. London.

[10] Barrett, C. E. 2011. Egyptianizing figurines from Delos: A study in Hellenistic religion. Leiden.

[11] Barr-Sharrar, B. 1990.'coroplast, Potter, And Metalsmith' in J.P. Uhlenbrock et al. The Coroplast's Art: Greek terracottas of the Hellenistic world, New Rochelle.

[12] Besques, S. 1992. Catalogue raisonne des figurines et reliefs en terre-cuite grecs, etrusques et romains.Vol. III. Paris.

[13] Barans, J. 1978. Egyptians and Greeks, pap. Brux.14.

[14] Barrett, C., 2015,"Terracotta Figurines and the Archaeology of Ritual: Domestic Cult in Greco-Roman Egypt", Figurines grecques en contexte Présence muette dans le sanctuaire, la tombe et la maison, ed. By Stéphanie Huysecom-Haxhi \&Arthur Muller, Presses Universitaires du Septentrion, France.

[15] Breccia, E. 1930. Terre Cotte Figurate Greche e Greco - Egizie del Museo di alessandria , in Monuments d'Egypte Greco - Romaine, II, Bergamo .

[16] Breccia, E., 1943, Monuments de l'Égypte Gréco-Romaine. Tome 2, Fasc. 1: Terrecotte figurate greche e greco-egizie del Museo di Alessandria. By Ev. Breccia. Pp. 90; 18 coloured and 57 other plates. Bergamo.

[17] Bieber, M., 1961. The sculpture of helllenistic age, Columbia university press, USA.

[18] Boardman, J.1984. Greek Sculpture, the Classical Period, London.

[19] Bol, R., 1989,"Porträt eines Buckligen", pp. 227-31 in P.C. Bol, ed. Forschungen zur Villa Albani. Katalog der antiken Bildwerke I, Berlin.

[20] Bonacasa, N.1960. "Segnalazioni Alessandrine II. Sculture minori del Museo Greco Romano di Alessandria", ArchClass. XII.

[21] Boutantin, C. 2014. 'Terres cuites et culte domestique. Bestiaire de l'Égypte gréco-romaine'. In: Religions in the Graeco-World 179. Leyde and Boston.

[22] Breccia, E. 1926. “Lampes.” In Monuments de l'Égypte gréco-romaine 1, Bergamo.

[23] Bussière, J.,\& Wohl, B., 2018, Ancient Lamps, In the J. Paul Getty Museum, the J. Paul Getty Museum press, Los Angeles.

[24] Burn, L., Higgins, R., 2001. Catalogue of Greek Terracottas in the British Museum: Volume III, London.

[25] Capponi, L., 2005. Augustan Egypt:e Creation of a Roman Province. New York: Routledge.

[26] Dasen, V. 2015. "Probaskania: Amulets and Magic in Antiquity." In The Materiality of Magic, edited by D. Boschung and J.N. Bremmer, 177-203. Paderborn: Wilhelm Fink.

[27] Dawson, R., 1927, Pygmies, Dwarfs, and Hunchback in Ancient Egypt, Med. Hist. 9.

[28] De Rosa, K., 2014, Roman and Late Antique Ceramic Oil Lamps in the Museum of Ancient Cultures: a Typological and Compositional Analysis, Macquarie University press, Sydney.

[29] Diodorus Siculus, Library, with an English Translation by C. H. Oldfather, London, William Heinemann, Ltd. (1989).

[30] Dunand, F., 1965, “Lantternes Graeco - Romaines d'Egypt”, dialogues d'History ancienne II, Paris.

[31] Dunand , F. 1990. Catalogue des terres cuites Greco Romain d'Egypte, Paris.

[32] Eckardt , H., 2002, Illuminating Roman Britain, Monographies Instrumentum ,Montagnac.

[33] Edgar, C., 1903. 'Greek Sculpture', Catalogue general des antiquities egyptiennes du musee du Caire, Le Caire.

[34] 1905. Minor antiquities. In Hogarth. Lorimer and Edgar 1905.

[35] Ekman, P. and Friesen, W., (1975) Unmasking the Face. Prentice-Hall.

[36] _ (2003) Emotions Revealed: Recognizing Faces and Feelings to Improve Communication and Emotional Life. New York.

[37] Ferruza, M., 2017, Ancienr Terracottas from South Italy and Sicily in the j. paul getty museum, the J. Paul Getty Museum press, Los Angeles.

[38] Fowler, B., 1989, the Hellenistic Aesthetic, Univ. of Wisconsin Press.

[39] Gazda, E., (1924-1935), Karanis: An Egyptian Town in Roman Times, Discoveries of the University of Michigan Expedition to Egypt, Ann Arbor. Kelsey Museum Publication.

[40] GIULIANI, L. 1987. "Die seligen Krüppel. Zur Deutung von Missgestalten in der hellenistischen Kleinkunst.” AA 1987. 
[41] Goldman, H., 1943, "Two Terracotta Figurines from Tarsus", AJA, 1, 22- 34.

[42] Grandjouan, C., 1961,"Terracottas and Plastic Lamps of the Roman Period" The Athenian Agora, Vol. 6, Terracottas and Plastic Lamps of the Roman Period, The American School of Classical Studies at Athens, New Jersey, 1 - 106.

[43] Grenfell, Bernard P. and Arthur S. Hunt 1899. Graeco-Roman branch: excavations for papyri in the Fayum; the position of Lake Moeris. Archaeological Report (Egypt Exploration Fund) (1898-1899).

[44] Grimm, G., 1998, 'Alexandria', in Mainz am Rhein, Die konigsstadt der hellenistischen welt, Berlin.

[45] Goldman, H., 1934, “Two Terracotta Figures from Tarsus”, (AJA 47.

[46] Haggag, M.2019. 'Cosmopolitan Trends in the Arts of Ptolemaic Alexandria, Edições Afrontamento'; in: CITCEM - Centro de Investigação Transdisciplinar «Cultura, Espaço e Memória»; Centro de Estudos Clássicos e Humanísticos; Alexandria University; Imprensa da Universidade de Coimbra.

[47] Haeger, K., 1988, the Illustrated History of Surgery, London.

[48] Halioua, B., 2004, Medicine in the Days of the Pharaohs, T. Kamal Al-Sayyid, Supreme Council for Culture. Cairo.

[49] Hemingway, S., Stone, R., 2019, "The New York Sleeping Eros: A Hellenistic Statue and Its Ancient Restoration", Bronzes grecs et romains : études récentes sur la statuaire antique, TECHNE n ${ }^{\circ} 45,47-63$. http://journals.openedition.org/techne/1266.

[50] Higgins, R.1969. Terracottas of Greek and Roman Antiquities in the British Museum, London.

[51] Himmelmann, N., 1983, Alexanria und der Redismus in der griechischem Knust, Tubingen.

[52] Hogarth, D.G., Lorimer,H., and Edgar,C., 1905. Naukratis, 1903. JHS 25.

[53] Karoglou, K., 2016, "The Collection of Greek Terracotta Figurines at The Metropolitan Museum of Art", Les Carnets de l'ACoSt, 14, $1-9$.

[54] Kleiner, D.1992. Roman Sculpture, London.

[55] Kozma, Ch., 2010," The Ancient Egyptian Dwarfs of the Walters Art Museum", Am J Med Genet Part A 152A:2556-2562.

[56] Lane, A. 1971. Greek Pottery, London.

[57] Lafl, E., Buora,M., Mastrocinque, A., 2012, "A New Osiriform Lamp from Antioch in the Hatay Archaeological Museum", Greek, Roman, and Byzantine Studies, 52.

[58] Laios, K., and Others, 2016" The depiction of acromegaly in ancient Greek and Hellenistic art", HORMONES, 15(4):570-571, Athens.

[59] Leca, A., 1983, La medecine egyptienne au temps des pharaons, Paris.

[60] Mariette, E, 1872. Album Du Musee De Polaq, Le Caire.

[61] Maspero, G.1908. Guide to the Cairo Museum, (T. by A. Quibell), Cairo.

[62] Moraw, S., 2011, "Visual Differences: Dionysos in Ancient Art." In A Different God? Dionysos and Ancient Polytheism. Edited byRenate Schlesier. Berlin, Germany: Walter de Gruyter GmbH \& Co. KG., 233-252.

[63] Muller, A., 1997, Études Thasiennes XV, Les terres-cuites votives du Thesmophorion. De l'atelier au sanctuaire, École française d'Athènes, 2 vol., Paris.

[64] Muratov,M.,2012,“The world's a stage...”: Some Observations on Four Hellenistic Terracotta Figurines of Popular Entertainers,International Journal of Humanities and Social Science, Vol. 2 No. 9.

[65] Nur Al-Din, A., 2001, Mawaqi wa Matahif Al-Athar Al-Misriyyah "The Sites and Museums of Egyptian Monuments", (Cairo: Al-Khalij Al-`Araby Publishing and Distribution.

[66] Nur Al-Din, A., 2002, Mawaqi Al-Athar Al-Yunaniyyah wa Al-Romaniyyah fi Misr "The Sites of Greek and Roman Monuments in Egypt", Cairo.

[67] Osborne, R., 2017, "Intoxication and Sociality: The Symposium in the Ancient Greek World," , Oxford Academic Journals. Web. 1

[68] Petrie, W. M. Fl. 1886. Naukratis, Part I, 1884-5. London.

[69] Pollitt, J., 1986. Art in Hellenistic Age, Cambridge.

[70] Perdrizet, P., 1921, Les Terres Cuites Greques d'Egypt de la collection Fouquet, Paris.

[71] Prinz, H.1908. Funde aus Naukratis,Beitrage zur Archaologie und Wirtschajtsgeschichte des VII.undVI.chr, Leigzig.

[72] Pedley , J . 2002. Greek Art and Archaeology, Third Edition, London.

[73] Reinach, S., 1889, Les gaulis dans l'arte antique, Paris. 
The Terracotta of Kyphosis Old Man From Faiyum Preserved in Egyptian Museum in Cairo Publication and Study

[74] Rifaat, A., 1958, Principles and Practice of Surgery, Cairo.

[75] Shier, L.1906. Terracotta Lamps from Karanis, Michigan.

[76] Smoláriková, K., 2016, "Egyptian Nocturnal Festival of Lamps in Honour of Athena-Neith", Studia Hercynia XX/1, 27-32.

[77] Stafford, E.2004. Ancient Greece, Life, Myth and Art, London.

[78] Stewart, A., 2014, Art in the Hellenistic World, Cambridge University Press.

[79] Süvegh, E., 2014. "Hellenistic grotesque terracotta figurines Problems of iconographical interpretation", DissArch Ser. 3. No. 2.

[80] Russell, D.2001.The Arts of Prose: The early Empire, in The Roman World, ed. John Boardman, Oxford University Press.

[81] Wace, A., 1904, "Grotesques and the Evil Eye", Annual of the British School at Athens, vol.10, The Council, British School Press, Athens, DOI: https://doi.org/10.1017/S0068245400002100, Published online by Cambridge University Press: 18 October 2013.

[82] Woodford, S., 1982. The Art of Greece and Rome, Cambridge Uni. Press.

[83] Thiessen, K., 2016, The (In)visibility of Slavery in Roman Archaeology: The Role of Material Culture, University of Sheffield press.

[84] Thomas, R. I. 2011. 'Terracotta figurines'. In Myos Hormos - Quseir al-Qadim. Roman and Islamic ports on the Red Sea 2: Finds from the 1999-2003 excavations, 79-84. D. P. S. Peacock and L. Blue (eds), BAR International Series 2286. Oxford: Archaeopress.

[85] _2015. 'Ptolemaic and Roman figures, models and coffin-fittings in terracotta' in: Villing et al. (eds.) Naukratis: Greeks in Egypt, the British museum press.

[86] Thomas, R. I. and Nicholson, P.T. 2013. Figurines. In Working in Memphis: The production of faience at Roman period Kom Helul, 41-74, P. T. Nicholson (ed.). Egypt Exploration Society. London.

[87] Török, L., 1995. Hellenistic and Roman terracottas from Egypt, Roma.

[88] Trentin, L., 2010, "Roman emperors and their deformed slaves: a case study of Commodus and the two hunchbacks", Greece \& Rome.

[89] Van De Graaff, K., Fox, S., La Fleur, K., 1997. Synopsis of Human anatomy and physiology, Boston.

[90] Vandorpe, K., 2012. 'Identity in Roman Egypt', in C. Riggs (ed.), The Oxford Handbook of Roman Egypt, Oxford.

[91] Vermeule ,C., 1968,"Graeco-Roman Statues: Purpose and Setting - I" , The Burlington Magazine, Vol. 110, No. 787 .

[92] Voegtle, S., 2016, "A Grotesque Terracotta Figurine of the First Century C.E. from Muralto, Ticino, Switzerland: Function, Use, and Meaning", Les Carnets de l'ACoSt, 15.

[93] Walker, S., Higgs, P., 2000, Cleopatra: Regina d'Egitto, Milan.

[94] Walker, S., Higgs, P., 2001, Cleopatra of Egypt: from history to myth. Princeton: Princeton University Press.

[95] Walters, H., 1914, Catalogue of the Greek and Roman Lamps in the British Museum, London.

[96] Westenholz, J., 2005, let there be light: Oil-lamps from the Holy Land. Jerusalem: Bible Lands Museum.

[97] Yeames, A., 1907, "An Ivory Statuette", Papers of the British School at Rome, Vol. 4, No. 4.

[98] Zanker, G., 2004, Modes of Viewing in Hellenistic Poetry and Art, Univ. of Wisconsin Press.

\section{AUTHOR'S BIOGRAPHY}

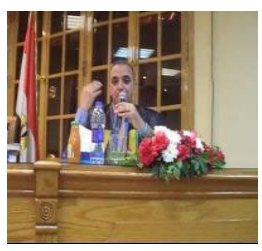

Mustafa Muhammad Qandil Zaied, Professor of History of Ancient civilization King Khalid University. Faculty of Humanities, KSA, Professor of classical Archaeology Ain Shams University, Faculty of Arts, Egypt

Citation: Mustafa Muhammad Qandil Zaied. "The Terracotta of Kyphosis Old Man From Faiyum Preserved in Egyptian Museum in Cairo Publication and Study" International Journal of History and Cultural Studies (IJHCS). vol 6, no. 3, 2020, pp. 1-9. doi: DOI: http://dx.doi.org/ 10.20431/2454-7654.0603001.

Copyright: () 2020 Authors. This is an open-access article distributed under the terms of the Creative Commons Attribution License, which permits unrestricted use, distribution, and reproduction in any medium, provided the original author and source are credited. 